\title{
WHAT DOES TRAUMA HAVE TO DO WITH POLITICS? CULTURAL TRAUMA AND THE DISPLACED FOUNDING POLITICAL ELITES OF ISRAEL AND TURKEY*
}

\author{
Shai M. Dromi \\ Harvard University \\ 33 Kirkland St. \\ Cambridge, MA 02138 \\ shai.dromi@g.harvard.edu
}

\author{
Gülay Türkmen ${ }^{\dagger}$ \\ University of Göttingen \\ Waldweg 26 \\ 37073 Göttingen \\ gulayt@gmail.com
}

Running head: What does trauma have to do with politics?

This is a pre-print of an article published in final form as Shai M. Dromi \& Gülay

Türkmen (2019) "What Does Trauma Have to Do with Politics? Cultural Trauma and the Displaced Founding Political Elites of Israel and Turkey”, The Sociological Quarterly, DOI: 10.1080/00380253.2019.1580547

\footnotetext{
* The authors are indebted to Jeffrey C. Alexander, Matthew Andersson, Roger Baumann, Noli Brazil, Deborah Davis, Maleah Fekete, Philip S. Gorski, Carly Knight, Michèle Lamont, Derek Robey, Liron Shani, and Philip Smith for their input on this project in various stages. This paper also benefitted from comments from the Supper Culture Club and the Comparative Research Workshop participants at Yale University and the ISF participants at the Harvard University Department of Sociology. Comments from the editors and the anonymous reviewers at The Sociological Quarterly have greatly improved the final version of the paper.

$\dagger$ Both authors contributed equally to this study and are listed alphabetically.
} 
ABSTRACT: Recent political events, such as Brexit and Trump's election, have inspired talk of collective trauma in academic publications and news outlets. Yet, scholars have been unclear about the processes that transform mundane political events into collective traumatic experiences. In this article, we ask how political factions come to interpret election outcomes as a trauma. We draw on cultural trauma theory to examine the ways state-founding political elites interpret their election losses. We show that such elites commemorate the loss by employing narratives that depict them as victims of unjust political processes, and simultaneously provide them with a sense of moral superiority. This enduring self-conception hinders subsequent efforts to draw new supporters or to change political strategies. We demonstrate this process using two empirical cases: the Israeli Labor Party and the Turkish Republican People's Party, both of which dominated their respective nations for decades until they were ousted through democratic elections. We suggest that cultural trauma theory can illuminate the reasons for some of the political deadlocks that shape newly-founded democracies' policies.

KEYWORDS: cultural trauma, political elites, political movements, democracy, Turkey, Israel 


\section{INTRODUCTION}

Recent political events like Brexit and Trump's victory have inspired talk of collective trauma in academic publications and news outlets (e.g., Gross 2016, Thirani Bagri 2017). Yet, we still know little about why broad political factions might find certain democratic processes traumatic and how these processes affect their collective identities. Cultural trauma theory has certainly provided tools to examine the relationship between trauma and collective identity, but scholars have primarily applied it to obvious sources of collective distress like natural disasters (Erikson 1995), war (Saito 2006), discrimination (Onwuachi-Willig 2016), genocide (Alexander and Dromi 2011), and political assassination (Eyerman 2011b, Türkmen-Dervişoğlu 2013). However, groups may also perceive nonobvious distress sources as traumas, like significant power shifts in democracies. In particular, political factions that have dominated for decades may commemorate losing political power as a disaster that has left deep wounds on their group identities. Since self-perceived victimhood can subsequently shape a group's political culture, understanding past election losses as cultural traumas can help explain present political strategies.

To examine the relationship between election losses and cultural trauma, we ask how founding political elites interpret losing political power in their respective nations. Building on Putnam (1976), we define founding political elites as groups that establish new political systems (through state-making or revolution) and then dominate them for prolonged periods. Founding political elites center around a political party, but also include other actors who believe they share values with the party, like related state officials, media persons, professional organizations, 
artists, business leaders, and intellectuals ${ }^{1}$. Such groups may hold power through undemocratic arrangements like a single-party system, or may dominate a democratic system without any realistic opposition (Arian and Barnes 1974). Founding elites provide an excellent case to study cultural trauma in politics: their downfall is a straightforward democratic outcome, but elite members - believing they play a crucial role in their national history and destiny - interpret the turnover as a tragedy for themselves and for their entire nation. We demonstrate this process by analyzing twin examples: the Turkish secular republican elite, politically represented by the Republican People's Party (CHP), and the Israeli socialist Zionists, historically represented by the MAPAI party (which became the modern Labor party) ${ }^{2}$. Both ruled virtually unchallenged in their first several decades, both generated a social elite that tied its identity to the party, and both eventually lost the popular vote, never regaining their former unchallenged domination.

The paper traces the ways the CHP and the MAPAI elites interpreted their ousting by examining the public narratives they developed to account for their downward political mobility. We use published biographies, memoirs, newspaper articles, and secondary sources, focusing on elite leadership responses to their unseating. We also assess the continuity of the narratives developed after the initial loss by examining founding elite responses to subsequent political events like further election losses, military interventions, and political assassinations. Despite specific differences between the cases, we show that Turkish and Israeli founding elite leaderships repeatedly denounced the public for rejecting them, depicted themselves as the sole

${ }^{1}$ E.g., the social elites associated with the Italian Christian Democracy, the Argentinian National Autonomist Party, the Indian National Congress, or the Tunisian Democratic Constitutional Rally.

${ }^{2}$ About Israel-Turkey comparisons see Rubin and Sarfati (2016) and Tepe (2008). 
legitimate leadership in their country, and predicted a dire fate for the country under the new leadership. Both factions have thus presented themselves as victims, who continuously endure assaults to their collective identity.

While election losses understandably disappoint any political faction, the experience of founding political elites in new democracies has unique characteristics. First, most established Western democracies have a concession speech tradition (Wagner-Pacifici 2001, Willyard and Ritter 2005), where the losing party admits defeat and commits to a self-scrutiny period in preparation for the next round. Newly founded democracies like Israel and Turkey lack such long-standing procedures. Without established routines to frame the loss as a self-improvement opportunity, founding elites may depict themselves as tragedy victims and question the validity of their democratic system. Second, founding elites in countries like Israel, Turkey, India, Algeria, and other new democracies, have seen themselves both as nation builders and as society builders, who transformed a traditional religious population into a secular, Westernized, modern society worthy of its own self-governed nation-state (Walzer 2015). For such political groups, losing leadership challenges their self-perceived role through rejection by the very society they had sought to transform. This limits their ability to recover and to appeal to new voters.

For democratic transition and survival studies (Kadivar 2018, Kapstein and Converse 2008, Viterna and Fallon 2008), the effects of cultural trauma demonstrate how a common democratic occurrence across new states affects their long-term political culture. The most crucial test for a young democracy is its first political turnover: the way founding political elites react to their ouster can affect the faith citizens uphold in democracy in the future. The narratives formed in this pivotal transition also set the stage for the ways opposition party supporters understand their place within the polity. As existing research on trauma and politics shows, a 
trauma narrative hinders possible pathways for political reconciliation (Hutchison and Bleiker 2008). Cultural trauma can thus explain why some founding political factions are slow to recuperate and to adapt their agendas, and why their hardline opponents often attract wider publics. Specifically, our analysis helps clarify why the Israeli left-wing has historically disadvantaged itself by alienating many religious and non-European-origin Israeli voters (Shapiro 1991). Since the Israeli left-wing often identifies as the pro-peace faction, its limited appeal to new voters bears direct implications for the Israeli-Palestinian conflict. Our analysis also helps understand the current deadlock in Turkish politics, and why the ruling Justice and Development party (AKP) constantly "threatens" its electorate with the possible return of the secularist CHP to power. Through a close-up of the CHP elites, the article sheds light on the ascent of the AKP and the authoritarian turn in Turkey, which has affected the entire Middle East (Akkoyunlu and Öktem 2016, Somer 2016).

This article similarly contributes to social movements studies by highlighting the ways a collectively held trauma memory shapes movement perceptions and framings. Social movements research has seen a cultural turn through increased attention to framing (Snow and Benford 1988), narrative (Polletta, et al. 2011), and emotion (Goodwyn and Jasper 2006). But as critics have noted, this literature has largely treated collective memory as a tool or an end at the hands of a movement and neglected the role memory plays in shaping how movements conceive of their aims and strategies (Doerr 2014). Understanding how cultural trauma structures movement self-perception can help explain both why some movements experience difficulties adjusting to new social circumstances and how movements develop resilience when facing adverse conditions (Abrutyn 2015). Thus, the current study can illuminate other cases of movement response to socio-political downturn as well. 


\section{THEORETICAL BACKGROUND}

Studies in collective memory have demonstrated that groups commemorate events in their histories through the prism of their present experience, in ways that shape their future orientations (Simko 2018). Collective memory, for this literature, refers not to the aggregated group member memories, but rather to social patterns of memorialization that are irreducible to individual experience (Olick 1999). In this, groups provide the social context that renders a past event meaningful and transmit its memory through public symbols, stories, and rituals (Halbwachs 1992). In particular, groups develop shared narratives that establish a causal link between an event in their history and their understanding of their present state (Polletta, et al. 2011, Somers 1994). Narratives identify roles like perpetrators and victims, assign responsibility for present beings, and provide moral justification for action (Smith 2005). Thus, different groups can remember similar events—including seemingly obvious trauma sources (war, earthquake, assassination, etc.) - in different ways. Some groups may construe the narrative positively, for example, by invoking a national defeat to place a barrier between a stigmatized past and a better present, as in the Japanese and West German World War II remembrances (Giesen 2004, Hashimoto 2015). However, other groups may construe the narrative negatively, perceiving themselves as victims and drawing on a mythologized "golden past" to imagine a better future and to act—often aggressively— to realize it (Boym 2008).

A cultural trauma is based on a particularly poignant shared narrative about the past. Cultural trauma occurs when group members believe they have experienced a disastrous event that has permanently altered their collective identity (Alexander 2004). Unlike psychological approaches to post-traumatic stress, cultural trauma research does not focus on a specific list of symptoms suffering individuals may exhibit. Instead, it looks at how groups come to perceive a past event as traumatic, and how they etch it into their collective memory through public 
mnemonic practices like periodic retelling of the event, artistic depictions, religious commemoration, or political speech ${ }^{3}$. Collective trauma memories can elicit emotions that bolster cohesion and intensify a sense of group identity (Hutchison and Bleiker 2008), highlighting group boundaries in the process (Lamont 1992), and can thus serve as a central identity marker for group members. As Abrutyn demonstrates about ancient Israel, the eightcentury BCE destruction of the Kingdom of Israel formed the basis for religious entrepreneurship that sharply demarcated boundaries between Jews and non-Jews (Abrutyn 2015). This way, a trauma memory enhanced Israelite group identity and ultimately helped Jewish long-term group survival in the diaspora.

Carrier groups are key to cultural trauma processes, forming a crucial link between a historical event and its inscription in collective memory as a trauma. Carrier groups work through social movements or other pressure groups to communicate the meaning of an event for their collective identity, to influence the public representation of their experience and to formulate moral claims on its basis (Eyerman 2011a, 460). These groups resemble institutional entrepreneurs who articulate new symbolic orientations for a broader public (through new cultural and moral frameworks), especially during institutional emergence or change (Eisenstadt 1980, Colomy 1998). Such actors create patterned ways to reinvoke past events and to draw links between them, group identity, and the present group situation, thus contributing to long-term group resilience (Abrutyn 2016, 333). While carrier groups may include political leaders, they may include artists, scholars, authors, media persons, or other social activists who invoke a shared repertoire of representations to articulate publicly the perceived effects of the trauma on

${ }^{3}$ This is in contrast to more micro-level work on the inter-generational trauma transmission through socialization and child rearing practices (e.g., Kellermann 2001a, 2001b). 
their group identity. The next sections show how the ousted MAPAI and CHP elites, as carrier groups, developed a narrative framework to account for their removal from power, the patterns they used to reinvoke this event, and the ways they boosted their group sense of self-worth despite these new circumstances.

\section{ANALYTIC STRATEGY}

In our analysis of the CHP and the MAPAI/Labor elites we use a "most different" case design (Seawright and Gerring 2008) ${ }^{4}$ : while acknowledging the differences between the two cases we build our comparison on the similarities in attitudes of the CHP and MAPAI/Labor elites. Despite their different historical origins and trajectories, both groups share an enduring belief that they are the architects of their respective nations and that they retain some ownership of them. They have espoused similar ideas about modernizing, Westernizing, and democratizing an inchoate populace into a nation (ideas comparable to those inspiring the founders of Pakistan, the Republic of India, and other twentieth-century post-imperial states). Both dominated their national political map for several decades (albeit under different political and historical conditions) and both had perceived an ultimate political change as unthinkable until they were democratically ousted. Analyzing both groups highlights the cross-national commonalities in the cultural-political experience of losing political power. Table 1 presents key information on the two cases.

TABLE 1 ABOUT HERE

\footnotetext{
${ }^{4}$ According to Seawright and Gerring (2008), in "most different" case design the two cases are different in all independent variables except for the independent variable of interest and the outcome.
} 
To understand how founding political elites account for their status change, we first focus on the public expressions the CHP and the MAPAI/Labor elites offered after their first election losses (1950 in Turkey, 1977 in Israel). We examine the core narratives by which each group explained the loss and articulated their views on their role in Israeli and Turkish societies. To evaluate the longevity of these narratives, we selected three subsequent confrontational events from the history of each party based on secondary literature. During such moments (or "trials" (Lamont 2012)) founding elite members responded to a challenge to group identity by articulating what they believed to be their core collective merits. These events exemplify the continuing salience of the narratives ${ }^{5}$. In Turkey, we evaluate the CHP elites' reactions to (1) the 1960 coup, when the military ousted the increasingly authoritarian Democrat Party (DP) and returned the CHP to power, (2) the 1999 elections, when the CHP remained outside parliament for the first time, and (3) the 2007 Justice and Development party (AKP) landslide victory. In Israel, we examine the MAPAI/Labor elites' reactions to (4) the 1982 Lebanon War, which elicited intense criticism of Israel's belligerence, (5) the 1995 assassination of Prime Minister Yitzhak Rabin, and (6) the 1996 right-wing Likud party electoral victory.

In line with our theoretical orientation, our analysis does not investigate individual elite members' psychological states, but rather examines the ways they found appropriate to publicly interpret and invoke these events. Our main sources include newspaper reports of party elites' public statements, biographies, and memoires. We first consulted existing secondary literature on the historical events in question, and identified party official biographies and memoires for

\footnotetext{
${ }^{5}$ Numerous other confrontational events exist but could not be included due to space constraints.
} 
analysis $^{6}$. To triangulate our findings and to counteract possible limitations our reliance on secondary literature may pose, we then scanned newspapers published in the immediate aftermath of each major event we examine (ranging from a one- to three-week period). In Israel, we rely primarily on the Left-leaning newspapers Davar (affiliated with MAPAI) and Ha'aretz (unaffiliated), and the centrist Yediot Aharonot and Maariv. In Turkey, we rely primarily on secular-republican Ulus and Cumhuriyet, the centrist Sabah and Milliyet ${ }^{7}$, and the left-liberal Radikal.

We focused on statements that offered public accounts of political affairs, paying specific attention to the way the elites connect events into causal narratives explaining their now-limited political power. We sorted their accounts based on the causal relations they offered, and built grounded categories based on their narratives, which we present below. The narratives we highlight recurred across sources and demonstrated the commonality of the framings the elites employ to explain their downfall. Crucially, we do not suggest that these are the only narratives CHP and MAPAI elites used, but rather show that these narratives dominated their public construal of the events and retained their salience for decades.

\section{Historical Context}

The historical democratic trajectories of Turkey and Israel, especially as they concern the CHP and MAPAI elites, differ significantly. The Turkish founding political elite was mostly comprised of young Ottoman administration officers who intended to bury the dynastic, semi-

\footnotetext{
${ }^{6}$ We particularly relied on Özel 1988, Turan 2002, Weitz 2011, and Weiss 1979 to identify specific events relating to the political transitions, but additional sources are cited in the findings section where relevant.

${ }^{7}$ Sabah and Milliyet changed hands under the AKP rule and are now owned by pro-AKP conglomerates. In 2016, the Doğan Media Group closed down Radikal.
} 
theocratic imperial past. This elite emerged around Mustafa Kemal Atatürk and the party he founded in 1923, known for most of its existence as the "Republican People's Party" (CHP). Aiming to secularize and modernize the country, they undertook a top-down nation-building project. They became known for their republican secularist ideology, later dubbed Kemalism. Until 1946, the CHP implemented a single-party regime, except for two unsuccessful transition attempts to multi-party democracy in 1924 and $1930^{8}$. Atatürk remained the party president until his death on November 10, 1938, when İsmet İnönü succeeded him9.

The moderate socialist "Party of the Workers of the Land of Israel" (MAPAI, the key precursor to the contemporary Israeli Labor Party) dominated Zionist institutions in Mandatory Palestine since the 1930s (Goldstein 2001). It never enjoyed the same single-party status as the CHP, as the first Israeli multi-party elections took place in 1949, several months after independence. The party ruled as part of coalitions but retained parliamentary and executive dominance until its 1977 downfall. Under the (often uncompromising) David Ben-Gurion leadership, the party espoused a centralized, often nepotistic organizational style. Ben-Gurion sought to build a Westernized nation free of religious orthodoxy and non-Western customs (Englard 1987). Like their Turkish counterparts, party associates dominated high-ranking positions in Israeli institutions. They maintained symbolic power by crediting MAPAI with the establishment of the state, endowing Ben-Gurion with an almost reverential aura (Shapiro 1991,

\footnotetext{
${ }^{8}$ For more about the Progressive Republican Party (Terakkiperver Cumhuriyet Fırkasi) and the Free Republican Party (Serbest Cumhuriyet Fırkast) see Zürcher 1991 and Emrence 2000. For an account of the single party period see Tunçay 2000 and Karpat 1991.

${ }^{9}$ On the period between 1938-1950 see Aydemir 1968 and Koçak 2007.
} 
$151)^{10}$. The party used institutionalized discrimination to marginalize populations that defied its views on Israeli society, like non-Jews, religious Jews, and non-European Jews, known as 'Mizrahi' (Khazzoom 2003).

Despite the differences in their democratic histories, in both countries a dominant party has traditionally represented a broad, secularist coalition represented by newspapers, unions, professionals, and intellectuals, among other actors. In each nation, this coalition perceived their values as superior to competing ideologies, thus deeming itself as the only political group worthy of ruling their country. While both parties espoused a discourse of democracy and modernity, both employed a paternalistic stance toward the citizenry, especially in their early years. BenGurion famously claimed, "I do not know what the people want. I know what is preferable for them to have!" (quoted in Cohen-Almagor, 1995: 483). Thus, Turkish and Israeli ruling party supporters were shocked when their political dominance abruptly ended.

In 1950, in the first democratically held multi-party elections in modern Turkish history ${ }^{11}$, the Democrat Party (DP) won by a landslide. "Many [of the DP's] deputies, and certainly its supporters, hailed from provincial cities and rural areas and had backgrounds in small-scale commerce outside the purview of the state. (This contrasted with the bureaucratic or military background of the majority of the CHP deputies)" (Acemoğlu 2014). This defeat caught

${ }^{10}$ Israeli sociologist Baruch Kimmerling (2001) described the MAPAI-led social elite as (1) Ashkenazi, that is European descent Jewish, rather than Asian or North-African ("Mizrachi"); (2) secular; (3) veteran settler, rather than newly immigrated; (4) socialist, or at least paying lipservice to socialism; and (5) nationalist, as opposed to communist or (in later years) post-Zionist.

${ }^{11}$ The first multi-party elections in Turkey were held in 1946, but are largely considered undemocratic because of the open-vote, secret-count method used then. 
the CHP completely unprepared (Güngör 2010). CHP member Hilmi Uran recalled being "quite sure that (...) the CHP was going to have a sweeping electoral victory" (quoted in Koçak 2014). Journalist Cüneyt Arcayürek observed that "the CHP was quite self-confident: it would win the elections all over the country" (1985: 213). The 1977 Israeli election caught its founding elite equally unprepared when MAPAI lost to the Likud party, under Menachem Begin's leadership (Reznik 2002) ${ }^{12}$. The Likud, representing a long tradition of dissent against socialist Zionism, appealed to Mizrahi and religious voters whom MAPAI had long alienated. Since MAPAI leaders perceived Mizrahi population as culturally inferior and, having "no leaders with sufficient education and culture", unable to organize politically (Goldstein, 2007: 7), the party made little effort to retain their support ${ }^{13}$.

The newly installed ruling parties were more socially conservative than the Labor and the CHP. They challenged the secularist ideology their predecessors espoused. The Turkish DP differed from the CHP by advocating for a greater role of Islam in public affairs. It also highlighted the rural values CHP elites have seen as inferior (Benli Altunışık and Tür 2005, 29). The Israeli Likud objected to the Labor's socialist secularism and drew Mizrahi and religious voters who felt - like their rural Turkish counterparts - that their values are finally getting a voice in politics. In both countries, the founding elites saw this transition as an offence committed against them (rather than a straightforward political failure), since they traditionally identified national values with their own ideology. The decades following these turnarounds saw

12 Although its name changed several times, the article refers to the movement as Labor throughout for consistency. For more on the 1977 turnaround see Arian 1995.

${ }^{13}$ See for example Yuval 2015. 
each group construct a narrative framework to explain how-despite its self-perceived special status in their national history—neither elite recaptured the same political power it had previously held ${ }^{14}$. Both groups represented their losses as an aberration of true democratic processes. This framework drew strict symbolic boundaries between the founding elite and the new rulers: it depicted the former as morally superior and absolved it of past errors, and portrayed the latter as incompetent, deceitful, and outright malicious.

The next section outlines three key narratives founding elite members used to construct this worldview in direct response to their removal, and also following subsequent events that challenged their political collective identity, such as further election losses, war, political violence, and coups-d'état. While we analyze these narratives separately, they are not mutually exclusive and speakers frequently invoked several simultaneously.

\section{EXPLAINING THE LOSS IN ISRAEL AND TURKEY}

\section{Narrative 1 - Manipulation, Deception, Incitement: Undemocratic Elections}

While the CHP and the Labor have traditionally presented themselves as dedicated to democracy, party elites depicted their election losses as a democratic failure due to misrepresentation or manipulation. After the 1950 defeat, CHP leader İsmet İnönü accepted that there are a "thousand fair and unfair reasons for this defeat" (quoted in Özel 1988: 149), but emphasized that, "the so-called 'intellectuals' have been indoctrinating the public against the CHP” (quoted in Güngör 2010: 202). Some CHP members suggested the public was misled to believe that, even if the conservative DP won the elections, İnönü would stay as Turkish

${ }^{14}$ Note that the Labor won the 1992 and 1999 elections, and the CHP won in 1973 and 1977 elections. Both led coalition governments following these elections. Yet, they never regained the same exclusive dominance they had enjoyed in previous decades. 
president. Hence, they posited, the public would understand its mistake after İnönü leaves the presidency (Ylldırmaz 2004: 133). Similarly, in Israel, Labor intellectuals invoked the term "historical accident" to explain their ousting (Gavron 2000, 144), attributing the result to a simple glitch that would soon be corrected. Some blamed right-wing leaders with "hijacking" the country by provoking the Mizrachi masses against the legitimate ruling party that had brought them to Israel in the first place.

Elite actors claimed that democratic mechanisms have been manipulated in subsequent elections and related political occurrences as well. In 1999, when the CHP came in under the $10 \%$ electoral threshold and remained — for the first time — outside of parliament, some blamed the then-CHP-leader, Deniz Baykal, while others echoed the CHP elites of the 1950s in accusing the media with leading an open fight against the CHP. News outlets supposedly manipulated the voters by portraying CHP candidates negatively or even ignoring them altogether (Coşkun 1999). Rauf Tamer, of Sabah, claimed that the media minimized CHP coverage and thus "jointly sent the CHP to the second league" (Tamer 1999).

Furthermore, CHP- and Labor-supporters insisted that the election results misrepresent true public opinion. One Labor member attributed the 1977 turnaround to "frustration, alienation, unease, estrangement, hatred, sympathy, respect, worship, disgust, scorn", rather than rational thought. He claimed that the "common claim of the $[$ Likud] party about the failures of the previous [Labor] government,..., as macabre as it is, captivated many hearts in the recent elections" (Weiss 1979, 22). Similarly, Deniz Baykal claimed in 1999 that the enthusiasm created by the capture of the Kurdish movement leader, Abdullah Öcalan, shortly before the elections, momentarily swayed public toward the opposing Democratic Left Party (DSP) (Sabah 1999). Once this enthusiasm would die out, he promised, the public would surely realize their 
mistake: abandoning the CHP, an "indispensable party" for Turkish democracy. Reporting on the $9^{\text {th }}$ CHP congress, Alev Coşkun claimed that "Baykal and his 'crew' believed that if the elections were to be repeated, the CHP could definitely pass the threshold and take its place in the parliament” (Coşkun 1999).

The CHP employed its long-time defense narrative after the AKP's sweeping election success in 2002 and 2007, describing the AKP as old counter-elites in a new disguise ${ }^{15}$. The shock CHP-supporters expressed at the 2007 AKP reelection ("These results cannot be correct!" (Milliyet 2007a)) was itself based on their belief that the 2002 AKP victory was a one-time success. According to this view, the AKP used state funds to buy votes with "legumes, pasta and coal", and exploited citizens' religious sentiments to unfairly sway public opinion. Melih Aşık, of Milliyet, asked: "Is it not true that money played a big role in these elections? Were state resources not employed for certain ends?” (Aşık 2007). Baykal endorsed this view: "This was not a fair election. Our party and organization did much to ensure its fairness but our rivals [the AKP] spent uncontrollable amounts of money" (Radikal 2007). Onur Öymen, then-CHP Vice President, claimed that "such an election would be revoked if it were held in a European country" (ibid).

Similarly, Israeli liberals accused conservatives of inciting the masses, and predicted dire consequences for Israeli society. For example, when an Israeli right-wing protestor threw a grenade into a 1983 left-wing demonstration against the Israel-Lebanon War, killing one person and injuring nine, liberal speakers blamed the ruling Likud party: "the hands were the hands of the grenade thrower, but the voice was the voice of [Minister of Defense] Ariel Sharon, who in

${ }^{15}$ AKP leader Erdoğan made it clear that he considers the AKP to be the heir of the Democrat Party. 
his demagoguery allowed his followers to incite themselves to the brink of a civil war," claimed one commentator (Davar 1983a). Labor leader Shimon Peres warned that "every act of physical violence is preceded by verbal violence... it starts with tomatoes, and continues with stones, and ends with grenades" (Davar 1983d). The protest organizers announced that "those who have turned incitement against political opponents into a norm... are those who created the basis for this tragedy" (Davar 1983c).

Other speakers criticized the "ordinary citizens" for their ignorance and their support of the Likud. After a right-wing-supporter shot Prime Minister Yitzhak Rabin in 1995, Labor representatives and the Rabin family—key agents in his commemoration —adamantly pointed to the Likud leadership as directly responsible (Vinitzky-Seroussi 2009). Left-wing commentators singled out Likud leader Benyamin Netanyahu, who Mrs. Rabin called "the architect of the incitement" against Rabin (Shmuelli, Reiss and Lovitch 2000) for having delivered a fiery speech in front of supporters waving posters depicting Rabin wearing SS uniform several weeks earlier. Labor leaders, including interim Prime Minister Shimon Peres, blamed radical rabbis for providing the shooter with theological justifications. "We cannot forget that the environment of incitement and violence can end in murder", Peres said (Zelikovich 2005). Despite these accusations, when left-wing speakers witnessed a new Netanyahu-headed Likud government rise 18 months later, Mrs. Rabin reportedly exclaimed "I feel like packing my bags and getting the hell out of this country". Indeed, post-elections left-wing demonstrators waved posters showing Netanyahu's smiling face and the verse "Hast thou killed, and also taken possession?".

\section{Narrative 2 - Ungrateful Publics: Why Has the Voter Left Us?}

While the first narrative placed much blame on political opponents, a second narrative turned to the voters themselves, blaming them with irrationality and ingratitude. Hüseyin Cahit 
Yalçin, the head columnist of the CHP's official newspaper, Ulus, suggested in 1950 that voting for the DP would equal ingratitude: "Try as the opposition may to cover the reality with lies, Turkish people's discretion and judgment will be enough for them to see the reality... Turkish people are not ungrateful" (quoted in Güngör 2010: 198). Similarly, prominent CHP member Faik Ahmet Barutçu deemed the Ankara voters "ungrateful" for not reelecting İnönü in his own electoral district (Barutçu 1977). Some Israeli actors—-like senior Labor official Yitzhak BenAharon — were equally scornful of the public vote after the 1977 election loss: "With all the respect I harbor for the public opinion, if this is the people's vote, then I am not willing to honor it". Activists portrayed the elections as a sharp split between the true Israeli and a new, unsavory nation. "Our Israel" claimed one writer, "had been superseded by another Israel: the Israel of Menachem Begin" (Gavron 1984, 183). Labor-supporters portrayed this mass abandonment as thanklessness, with one party official wondering "at the disjuncture between the industrial, military, demographic, economic, and cultural improvements that occurred in Israel since its foundation, under Labor movement leadership, and its abandonment by scores of voters in such a callous way" (Weiss 1979, 9-10).

Following the 1977 turnaround, comments to this effect would exacerbate Mizrahi resentment toward the Labor. Mordechai Gur, senior Labor leader and former Chief of Staff, famously promised a Likud-supporter crowd a fate similar to "the Arabs", as he called out from a podium: "just like their shouting didn't help them, and we smashed them, your shouting will not help you and we will smash you too!" Others commented disparagingly about the Likud-voter irrationality, laziness, and even savagery (stereotyping them as Mizrahi), in stark contrast to the left-wing-voter. 
Similarly, when the AKP gained a second term as a single-party government in 2007, CHP circles primarily reacted with disbelief and resentment towards the voters (Ciddi 2008). "In a period when most of our citizens are experiencing such hardship the fact that the governing party could increase its votes can only be explained by irrationality" exclaimed Onur Öymen, CHP Vice President, in a press statement (Sabah 2007). "If you still vote for the governing party, despite being distressed and hungry, and despite your daily criticisms against that party, then there must be something illogical about this" (Milliyet 2007b). Oktay Akbal, of Cumhuriyet, was clearly angry about the "people's choice": "What to write? (...) I was not expecting these results. Shock? Anger? I feel both! (...) Can it be that [the] famous proposition that 'fifty per cent of the Turkish people are stupid' is not unfounded after all?" (Akbal 2007). Another columnist, Emin Çölaşan, of Hürriyet, wrote: "It looks like unemployment, poverty, terrorism, foreign policy mistakes, injustice, inequality do not constitute any problem for half the population...It looks like the public is quite content with the current situation" (Çölaşan 2007).

After a religious, Mizrahi, right-wing Israeli assassinated Prime Minister Rabin in 1995, Labor-supporters rejected the "bad apples" explanation some right-wing speakers had offered. left-wing-supporters insisted instead that the shooter represented the religious right as a whole, which the preceding political demonstrations against territorial concessions had roused. "No incited masses and no violent rabble will make us forget what happened here, and the killer who came from their own lines to take you away," said Rabin's daughter in a memorial ceremony (Rabin-Filosof 1998) ${ }^{16}$. The shooter "was part of a well-defined camp, which is willing to accept under certain conditions even a political assassination... this narrow camp has a huge right-wing

16 The Rabins played an unusually dominant role in shaping the official commemoration of the shooting (Vinitzky-Seroussi 2009). 
backing" (Melamed 2000). When the right-wing continued to protest after a short reprieve, and ultimately regained political power, the Left presented it as "unrepentant". In a memorial to Rabin, his son-in-law blamed the entire right-wing for being "unwilling to denounce the murder of their prime minister by a cowardly Jew". He claimed the assassination has "turned the People of Israel overnight into a part of the Middle Eastern culture... Israel after the murder is worse than the naïve Israel before the murder. Then we could at least say that we are not like that. No more" (Filosof 1997). Conversely, speakers portrayed Rabin as the "true" Israeli, who one commentator described as "the first Jewish flower to bloom in the homeland, from out of the ashes of exile and the Holocaust" (Gabriel Ben-Simchon, quoted in Peri 2000, 183). Thus, the left-wing addressed the shock of the assassination using tropes developed after the 1977 loss.

\section{Narrative 3 - Whatever it Takes to Defend "Democracy"}

A third narrative expanded on the consequences of the regime change. Here, CHP and Laborsupporters depicted the elections as giving rise to unfit political leaders. This narrative portrayed the new leaders as steering their nations away from their secular democratic nature, toward Islamism in Turkey and warmongering in Israel.

Israeli Labor circles have traditionally seen the right-wing as "not prepared, unfortunately, either emotionally or intellectually" to undertake rational diplomacy (Shapiro 1991, 154). By contrast, "the Labor movement founded and led the State of Israel until 1977... Had it taken the counsel of [the Right], it is doubtful that the state would have been founded" (Weiss 1979, 24). Likewise, the secular Republican Turkish elites saw the CHP as the national "parent" and feared that without its rule the country would return to a dark past of ignorance and religiosity. 
Right after the 1950 elections, İnönü warned "that this homeland, built with blood and tears in thirty years, will be devastated in the hand of irresponsible politicians who care neither about their responsibilities towards the parliament nor about those towards the nation" (quoted in Kili 1976: 114). CHP's 1957 election declaration also cautioned: "If...our glorious nation wills so and the CHP takes over the government we will make sure that the basic rights of citizens... are no longer in the perilous condition they are in" (quoted in Kili 1976: 127). This fear echoed in the 2000s: In 2007 65\% of CHP-voters reported they did so to "protect laïcité and democracy in Turkey" (Kahraman 2007). Cüneyt Arcayürek of Cumhuriyet put this fear as follows: "On one side are those...who are in favor of transforming the republic to a US-satellite, miserable 'ummah' in the guise of 'moderate Islam'. On the other hand are those who defend laïcité, democracy, the constitution and national interests, those who defend Atatürk's Republic" (Arcayürek 2007). AKP's landslide victory, ironically, became a raison d'être for the CHP: many CHP members believed Turkey needed CHP more than ever given AKP's recurring victories. In 2006, the pro-CHP daily Cumhuriyet initiated an advertorial campaign to highlight the "perils of the AKP rule" with the slogan: "Are you aware of the imminent danger?" The question alluded to the danger of Islamism the AKP advocated. This attitude became clear in the mass rallies organized to protest the presidential candidacy of Abdullah Gül, an AKP MP at the time, in April and May 2007. Rally participants expressed concern mainly about the Islamist threat and vowed to "preserve and protect the secular Republic" at whatever cost.

In Israel, the Labor continuously warned against the allegedly growing belligerence of the hawkish Likud. For example, when news reached Israel about the 1982 Sabra and Shatilla Massacre, in which—with Israeli forces' knowledge and indirect backing—between 328 and 
3000 Palestinians and Lebanese Shiites were killed in Beirut ${ }^{17}$, left-wing and centrist circles widely denounced the government. They tied the massacre to a preexisting brutal undercurrent in the Likud administration. (Indeed, a commentator had warned before the 1981 elections that a second Likud term would mean "in James Bond's terms, a license to kill” (Barnea 1981).) Davar, the Labor-affiliated newspaper, blamed the prime minister for "having turned our image monstrous," calling the massacre the "culmination of a moral bankruptcy" (Zemer 1982). Crucially, left-wing critics asserted that Israeli wars fought under the Labor rule had been defensive and unavoidable, as opposed to Likud-era wars that they portrayed as reckless: "In 1982, for the first time, Israel initiated a war, bombed and shelled heavily populated areas, invaded an Arab capital, and intervened in the affairs of a neighboring state" (Gavron 1984, 6-7). They blamed the Likud government for turning "deceit and charlatanism into common governmental practices, thereby corrupting public discourse" (Davar 1983b). Thus, newspapers compared contradicting accounts military and government officials offered about the Beirut events, with several demanding an impartial investigation “preferably of [the government's] own volition rather than in response to public urging" (Davar 1982). Commentators blamed the Minister of Defense with deceiving his fellow cabinet members (Gavron 1984), portrayed the Prime Minister as incompetent (Melone 1985), and accused the foreign minister of ignoring information about the ongoing massacre and failing to intervene. Others described the government's disregard for procedures that "a democratic and morally fit nation follows" as "the root of evil" (Landers 1983).

${ }^{17}$ Estimates vary dramatically between sources; see Melone, 1985: 396. 
In the extreme, actors drew on the widespread anxiety over the democratic character of the nation to put democracy on hold, as was the case in several Turkish coups d'état. In May 1960, the Turkish military, disturbed mainly by the DP's religious conservatism and authoritarian tendencies, took power through a coup d'état, banned the political activities of the DP, and executed the party leader, Adnan Menderes, and two other cabinet members ${ }^{18}$. This was the first in a series of coups Turkey experienced over half a century. When the military announced the coup, CHP circles welcomed the news with relief and joy, believing the military was returning the CHP to power (Bila 2008). İnönü clarified that "the May $27^{\text {th }}$ revolution is not linked to any political party (...) the CHP neither leads the May 27 movement nor is involved in it" (quoted in Kili 1976: 136-137), but he also underlined that "the change in power, carried out by the intervention of the glorious Turkish Armed Forces, is a legitimate revolutionary act... The aim of this revolution is to carry out general elections as soon as possible and deliver the administration to the will of the people... The CHP is grateful for and appreciative of this revolution the sole aim of which is to establish and institute a legal democratic system" (quoted in Kili 1976: 136137).

While the military junta handed administration back to civilian hands with the 1961 elections, and while researchers agree that the 1960 coup helped create the most democratic constitution in Turkish history, the intervention remains an undemocratic act. Yet, leading CHP figures believed it was "the Menderes [DP] government itself that triggered the military's

${ }^{18}$ Some accused CHP of backing the executions. However, İnönü wrote a plea to the junta's Committee of National Unification (formed by the junta members) asking for forgiveness for Menderes and others: http://www.ensonhaber.com/inonunun-mbkye-gonderdigi-menderesmektubu-2012-09-24.html 
involvement in politics" (Rustow 1964: 366). In April 1960, İnönü warned the DP of the impending coup: "If human rights are not implemented and citizen rights are abridged (...) it is unavoidable that a coup takes place (...). If it ever takes place, it will be carried out by those who are unrelated to our party [but] if you continue in this way, even I cannot save you! When the conditions are ripe, a military coup is a legitimate right for nations" (quoted in Bila 2008: 159).

CHP's support for the coup contradicted its longstanding pretense to stand for democracy. In 1950, in a letter to his son, İnönü described CHP willingness to allow the DP to rule as "a source of pride for the nation and for all of us" (quoted in Özel 1988: 148-49). He was also quoted promising that if the CHP lost, he would say "look, this honor is also mine, you will never be able to find someone as patient as me" (Ulus 1950). Two days after the 1950 elections, an article in Ulus praised İnönü as follows:

"Atatürk carved the statue of democratic reform, İnönü gave life to it. As a president who has total (dictatorial) power, İsmet İnönü... brought onto stage the importance of the 'national will'. Just like he has shown us how a democratic regime can be founded, he will teach us how a serious, conscious and patriotic opposition can be" (Hüseyin Cahit Yalçin, quoted in Bakacak 2013: 544).

\section{DisCUSSION AND CONCLUSION}

What does trauma have to do with politics? How do political actors, especially founding political elites, interpret, remember, and frame political events as traumatic? What implications does this hold for the state of democracy in their countries? While both in Turkey and in Israel the fateful political transitions were through routine elections, we have shown that the Turkish and Israeli founding political elites-like their counterparts in Pakistan, India, Algeria, and other states born in the $20^{\text {th }}$ century — cultivated a shared set of victimhood narratives lamenting their "wrongful" removal from office. But in framing the electoral defeat as a severe blow to their 
own identity, founding elites have also highlighted their perceived virtues as standing for democracy, secularism, and progress (in stark contrast to their opponents). This way, cultural trauma has also served these groups as a key source of cohesion and resilience despite the changing socio-political conditions.

Given the salience of cultural trauma in the political sphere, cultural trauma scholarship would benefit from expanding its reach from obviously traumatic events like assassinations, catastrophes, or genocides to nonobvious events like democratic losses. Indeed, we drew fruitfully on this theory to demonstrate how the founding Israeli and Turkish political elites interpreted routine democratic workings as traumatic. The strength of cultural trauma theory is that — unlike PTSD approaches — it does not involve diagnosing individuals against a list of possible symptoms to determine whether they suffer from trauma (Alexander 2004). Instead, cultural trauma approach examines how groups develop the belief that they are traumatized without making judgments about whether that belief is warranted. The approach is based on the understanding that groups can assign different meanings to comparable events-what one group might find insignificant, another group may see as traumatic (Eyerman 2011b). (Indeed, this article does not make judgments about whether CHP- and Labor-supporters justly believe they are victims, and it does not question the gravity of the events analyzed, like the coups-d'état or the assassination.) Expanding cultural trauma analyses to nonobvious and controversial sources of distress, as the current article does, would fully capitalize on the potential of this theory.

Our findings also highlight the role collective memory plays in structuring social movements' self-perception and strategies for the future, a role that few social movements studies have closely examined (with important exceptions such as Doerr 2014 and Armstrong and Crage 2006). But since many movements organize around specific grievances they seek to 
address, a cultural trauma framework can help identify the links movement members draw between a commemorated past and present activism. Furthermore, collectively held memories of movement failure (and their reproduction through certain narratives) can explain why some movements are reluctant to adjust to changing socio-political conditions - especially when they continuously deploy strategies that have proven ineffective over time. In political activism, movements that resent the publics that voted against them are unlikely to gain new supporters, as the CHP and Labor cases show. Future work could compare the founding elite narratives with their political opponent interpretations, and shed further light on how the elite experience has influenced its perception of the democratic processes at hand. Overall, cultural trauma is an important addition to the collective mobilization research toolkit, as it bridges collective memory studies with social movement studies.

Additionally, the case of Israel and Turkey sheds light on the crucial role of founding political elites in shaping long-term democratic cultures. Since political elites can use their political leverage to monopolize resources in other spheres (e.g., economic, cultural, military) (Bourdieu 1996, Milner 2014), their worldviews can stay relevant in their society regardless of government changeovers. Thus, founding political elite interpretation of democratic turns-ofevents carries important implications for the broader well-being of a democracy. To address the trauma of their displacement, political actors usually resort to restorative attempts. Yet, in trying to fix the broken order, they manipulate emotions in such a way that "healing often becomes more about retribution..., rather than a long-term project begetting peace, collaboration and emotional catharsis" (Hutchison and Bleiker 2008: 385). A cultural trauma narrative can construe elections as a zero-sum game and demonize rival parties and their constituents. As we have shown, retribution aspirations may even move actors to support undemocratic acts in hopes 
of restoring their power, posing a severe threat to democracy. The insights from Israel and Turkey can help illuminate other new democracies or post-revolutionary cases, like Mexico under the Mexican Institutional Revolutionary Party (PRI, in power 1929-2000) or the Italian First Republic under the Christian Democratic Party (1946-1994). Additional work should examine longer-standing democracies, which may harbor a shared acceptance of "the rules of the game", and the extent to which elites interpret changeovers as traumas in those countries.

Finally, the case of the CHP and Labor elites contributes to our understanding of elite downward mobility, a neglected question in studies of elites more generally. Despite the burgeoning literature on elites, scholars have been more interested in the continuing elite monopolization of social resources despite changing social circumstances (Khan 2012, Rivera 2015) and in elite identity cultivation (Howard 2008, Sherman 2017) than in the ways losing status affects elite identity ${ }^{19}$. Since Milner (2014) has shown that elite groups may retain disproportionate influence even after losing dominance in one sphere, it is crucial to understand how they maintain their group identity as "elites" in changing social circumstances. Cultural trauma theory captures the effects of such a shock on (former) elites, and should inform future studies in this area.

\section{REFERENCES}

Çölaşan, Emin. 2007. "Sürpriz." Hürriyet, July 24. Özel, Sevgi, ed. 1988. Baba İnönü'den Erdal Inönü’ye Mektuplar. Ankara: Bilgi Yayınevi. Aş1k, Melih. 2007. "Ne Mesaj Verdi?" Milliyet, July 24. Abrutyn, Seth. 2015. "Pollution-Purification Rituals, Cultural Memory and the Evolution of Religion: How Collective Trauma Shaped Ancient Israel." American Journal of Cultural Sociology 3 (1): 123-155.

${ }^{19}$ Elites studies have a much longer history in sociology, which cannot be fully covered here. See Khan 2012 for a review. 
Abrutyn, Seth. 2016. "Why Groups Matter to Sociocultural Evolution: How Religio-cultural Entrepreneurship Drove Political and Religious Evolution in Ancient Israel." Comparative Sociology 15 (3): 324-353.

Acemoğlu, Daron. 2014. "The Failed Autocrat: Despite Erdogan's Ruthlessness Turkey Is Still on Track." Foreign Affairs, May 22.

Akbal, Oktay. 2007. "Bir Kez Daha Ne Yazmalı Derken." Cumhuriyet, July 24.

Akkoyunlu, Karabekir, and Kerem Öktem. 2016. "Existential Insecurity and the Making of a Weak Authoritarian Regime in Turkey." Southeast European and Black Sea Studies 16 (4): 505-527.

Alexander, Jeffrey C. 2004. "Toward a Theory of Cultural Trauma." In Cultural trauma and collective identity, by Jeffrey C. Alexander, 1-30. Berkeley CA: University of California Press.

Alexander, Jeffrey C., and Shai M. Dromi. 2011. "Trauma construction and moral restriction: The ambiguity of the Holocaust for Israel." In Narrating trauma: On the impact of collective suffering, edited by Ron Eyerman, Jeffrey C. Alexander and Elizabeth Butler Breese, 107-132. Boulder, CO: Paradigm Press.

Arcayürek, Cüneyt. 2007. ""Pilavdan Dönenin..."." Cumhuriyet, July 23.

Arian, Alan, and Samuel H. Barnes. 1974. "The Dominant Party System: A Neglected Model of Democratic Stability." The Journal of Politics 36 (3): 592-614.

Arian, Asher. 1995. Security Threatened. Cambridge: Cambridge University Press.

Armstrong, Elizabeth A., and Suzanne Crage. 2006. "Movements and Memory: The Stonewall Myth." American Sociological Review 71 (5): 724-751.

Aydemir, Şevket Süreyya. 1968. Ikinci Adam: Ísmet İnonü. Vol. 2. İstanbul: Remzi Kitabevi. Bakacak, Alper. 2013. "1950 Seçimleri Sonrası Ulus Gazetesi'nin Muhalefete Geçişi." Atatürk Üniversitesi Türk Inkilap Tarihi Enstitüsü Atatürk Yolu Dergisi 51: 541-561.

Barnea, Nahum. 1981. Dvar Hashavua, May 29.

Barutçu, Faik Ahmet. 1977. Siyasi Anılar. Istanbul: Milliyet Yayınları.

Benli Altunışık, Meliha, and Özlem Tür. 2005. Turkey: Challenges of Continuity and Change. New York: RoutledgeCurzon.

Bila, Hikmet. 2008. CHP: 1919-2009. 4th. İstanbul: Doğan Kitap.

Bourdieu, Pierre. 1996. The State Nobility: Elite Schools in the Field of Power. Stanford, CA: Stanford University Press.

Boym, Svetlana. 2008. The Future of Nostalgia. New York: Basic Books .

CNN Türk. 2010. Erdoğan'ın gündeminde Adnan Menderes vardl. August 5. Accessed October 9, 2017.

https://www.cnnturk.com/2010/turkiye/08/05/erdoganin.gundeminde.adnan.menderes.var di/585754.0/index.html.

Coşkun, Alev. 1999. "Kurultayın Değerlendirilmesi." Cumhuriyet, June 2: 2.

Cohen-Almagor, Raphael. 1995. "Cultural Pluralism and the Israeli Nation-Building Ideology." International Journal of Middle East Studies 27: 461-484.

Colomy, Paul. 1998. "Neofunctionalism and Neoinstitutionalism: Human Agency and Interest in Institutional Change." Sociological Forum 13 (2): 265-300.

Davar. 1981. Davar, September 10: 14.

- 1982a. "Former Minister of Justice Tzadok: The Official Announcements after the Massacre Contradict Statements Made by Sharon and Raful before the Massacre." Davar, September 20: 2 . 
—. 1982. "Former Minister of Justice Tzadok: The Official Announcements after the Massacre Contradict Statements Made by Sharon and Raful before the Massacre." Davar, September 20: 2 .

—. 1983. "From Peace for the Galilee to a Grenade in Jerusalem." Davar, February 11: 1.

—. 1983. "Hadin Vehacheshbon." Davar, February 7: 5.

—. 1983. "Peace Now: Not a Civil War." Davar, February 11: 1.

—. 1983. "Peres: Intimidation." Davar, February 11: 1.

—. 1982b. "The Shame of Beirut." Davar, September 20: 5.

—. 1983e. "What are you even talking about?" Davar, February 8: 3.

Doerr, Nicole. 2014. "Memory and Culture in Social Movements." In Conceptualizing Culture in Social Movement Research, edited by Britta Baumgarten, Priska Daphi and Peter Ullrich, 206-226. London: Palgrave Macmillan.

Eisenstadt, S. N. 1980. "Cultural Orientations, Institutional Entrepreneurs, and Social Change: Comparative Analysis of Traditional Civilizations." American Journal of Sociology 85 (4): 840-869.

Emrence, Cem. 2000. "Politics of Discontent in the Midst of the Great Depression: The Free Republican Party of Turkey (1930)." New Perspectives on Turkey 23: 31-52.

Englard, Izhak. 1987. "Law and Religion in Israel." The American Journal of Comparative Law 35 (1): 185-208.

Erikson, Kai. 1995. "Notes on Trauma and Community." In Trauma: Explorations in memory, edited by Cathy Caruth, 183-199. Baltimore, MD: Johns Hopkins University Press.

Eyerman, Ron. 2011a. "Intellectuals and Cultural Trauma." European Journal of Social Theory 14 (4): 453-467.

-. 2011b. The Cultural Sociology of Political Assassination: From MLK and RFK to Fortuyn and Van Goth. New York: Palgrave MacMillan.

Filosof, Avi. 1997. "Speech at Official Yitzhak Rabin Memorial." The Yitzhak Rabin Center. 12November. Accessed 2014 йил 15-October. www.rabincenter.org.il/Web/He/Persona/People/Eulogy/Pilosof/Default.aspx.

Güngör, Süleyman. 2010. "14 Mayıs 1950 Seçimleri ve CHP’de Bunalım." SDU Fen Edebiyat Fakültesi, Sosyal Bilimler Dergisi 21: 193-208.

Gavron, Daniel. 1984. Israel after Begin: A Noted Journalist Reports on Present Reality and Future Possibility. Boston: Houghton Mifflin.

- 2000. The Kibbutz: Awakening from Utopia. Lanham, MD and Oxford: Rowman \& Littlefield.

Giesen, Bernhard. 2004. Triumph and trauma. Boulder, CO: Paradigm Publishers.

Goldstein, Yaacov N. 2001. "Labour and Likud: Roots of their Ideological-Political Struggle for Hegemony over Zionism, 1925-35." Israeli Affairs 8 (1-2): 79-90.

Goodwyn, Jeff, and James M. Jasper. 2006. "Emotions and Social Movements." In Handbook of the Sociology of Emotions, edited by Jan Stets and Jonathan Turner, 611-636. Boston, MA: Springer.

Gross, Neil. 2016. "Are Americans Experiencing Collective Trauma?" The New York Times. December 16. Accessed March 29, 2017. https://www.nytimes.com/2016/12/16/opinion/sunday/are-americans-experiencingcollective-trauma.html?_r=0.

Gvirts, Ya'el. 2003. Yeled lo ratsui : Yitshak Ben Aharon--biyografyah ințimit. Tel Aviv: Yedi'ot aharonot. 
Halbwachs, Maurice. 1992. On Collective Memory. Edited by Lewis A. Coser. Chicago: The Univ. of Chicago Press.

Hashimoto, Akiko. 2015. The Long Defeat: Cultural Trauma, Memory, and Identity in Japan. New York: Oxford University Press.

Howard, Adam. 2008. Learning Privilege: Lessons of Power and Identity in Affluent Schooling. New York: Routledge.

Hutchison, Emma, and Roland Bleiker. 2008. "Emotional reconciliation: Reconstituting Identity and Community after Trauma." European Journal of Social Theory 11 (3): 385-403.

Jasper, James M. 2007. "Cultural Approaches in the Sociology of Social Movments." In Handbook of Social Movements across Disciplines, edited by Bert Klandermans and Conny Roggeband, 59-109. New York: Springer.

Kadivar, Mohammad Ali. 2018. "Mass Mobilization and the Durability of New Democracies." American Sociological Review 83 (2): 390-417.

Kahraman, Hasan Bülent. 2007. "Seçimi Okumak-3: CHP." Sabah, July 31.

Kapstein, Ethan B., and Nathan Converse. 2008. The Fate of Young Democracies. Cambridge: Cambridge Univ. Press.

Karpat, Kemal. 1991. "The Republican People's Party, 1923-1945." In Political Parties and Democracy in Turkey, edited by Metin Heper and Jacob M. Landau, 24-42. London: Tauris.

Kellermann, Natan P. F. 2001. "The Long-Term Psychological Effects and Treatment of Holocaust Trauma." Journal of Loss and Trauma 6 (3): 197-218.

Kellermann, Natan P. F. 2001. "Transmission of Holocaust trauma--An integrative view." Psychiatry 64 (3): 256-267.

Khan, Shamus R. 2012. "The Sociology of Elites." Annual Review of Sociology 38: 361-377.

Khazzoom, Aziza. 2003. "The Great Chain of Orientalism: Jewish Identity, Stigma Management, and Ethnic Exclusion in Israel.” American Sociological Review 68 (4): 481-510.

Kili, Suna. 1976. 1960-1975 Döneminde Cumhuriyet Halk Partisi’nde Gelişmeler: Siyaset Bilimi Açısından Bir İnceleme. İstanbul: Boğaziçi Üniversitesi Yayınları.

Kimmerling, Baruch. 2001. The End of Ashkenazi Hegemony [Hebrew]. Tel Aviv: Keter.

Koçak, Cemil. 2014. CHP'nin 1950 Seçimi Öncesindeki Beklentileri [CHP's Expectations Before the 1950 Elections]. May 17. Accessed September 29, 2014. http://haber.stargazete.com/yazar/chpnin-1950-secimi-oncesindeki-beklentileri/yazi884259.

—. 2007. Türkiye'de Milli Şef Donemi: 1938-1945 . 3rd. Vols. 1-2. İstanbul: İletişim Yayınları.

Lamont, Michèle. 1992. Money, Morals, and Manners: The Culture of the French and American upper-middle class. Chicago, IL: University of Chicago Press.

Lamont, Michèle. 2012. "Toward a Comparative Sociology of Valuation and Evaluation." Annual Review of Sociology 38: 201-221.

Landers, Israel. 1983. "The Black Flags of the Kahan Commission." Davar, February 8: 5.

Maariv. 1982. "Behind Closed Doors." Maariv, December 9: 34.

Melamed, Arianna. 2000. "The Memory Fades Away [Hebrew]." Ynet. November 4. Accessed October 14, 2014. http://www.ynet.co.il/articles/0,7340,L-228649,00.html.

Melone, Linda A. 1985. "The Kahan Report, Ariel Sharon and the Sabra-Shatilla Massacres in Lebanon: Responsibility under International Law for Massacres of Civilian Population." Utah Law Review 373-435. 
Milliyet. 2007a. "İstanbul İl Merkezi’nde Hüsran." Milliyet. July 23. Accessed October 9, 2014. http://www.milliyet.com.tr/2007/07/23/siyaset/siy02.html.

—. 2007b. "CHP'li Öymen: Sıkıntıya Rağmen AKP'ye Oy Veriliyorsa Bu Mantıkla Açıklanmaz." Milliyet, July 23.

Milner, Murray. 2014. Elites: A General Model. New York: Polity.

Onwuachi-Willig, Angela. 2016. "The Trauma of the Routine: Lessons on Cultural Trauma from the Emmett Till Verdict." Sociological Theory 34 (4): 335-357.

Peri, Yoram. 2000. "The Media and the Rabin Myth: Reconstruction of the Israeli Collective Identity." In The Assassination of Yitzhak Rabin, edited by Yoram Peri, 175-194. Stanford, CA: Stanford University Press.

Polletta, Francesca, Pang Ching Bobby Chen, Beth Gharity Gardner, and Alice Motes. 2011. "The sociology of storytelling." Annual Review of Sociology 37: 109-130.

Putnam, Robert D. 1976. The Comparative Study of Political Elites. Englewood Cliffs, N.J.: Prentice Hall.

Rabin-Filosof, Dalia. 1998. "Speech at the Official Yitzak Rabin Memorial." The Yitzhak Rabin Center. 1-November. Accessed 2014 йил 15-October. www.rabincenter.org.il/Web/He/Persona/People/Eulogy/Dalia/Default.aspx.

Radikal. 2007. "Baykal'ın Acelesi Yok." Radikal, August 2.

Raviv, Amiram, Avi Sadeh, Alona Raviv, Ora Silberstein, and Orna Diver. 2000. "Young Israelis' Reactions to National Trauma: The Rabin Assassination and Terror Attacks." Political Psychology 21 (2): 299-322.

Reznik, Shlomo. 2002. "Political Culture in Israel in the Era of Peace: The Jewish Underground and the Conscientious Objection Movement, 1979-1984." Peace \& Change 27 (3): 357384.

Rivera, Lauren A. 2015. Pedigree: How Elite Students Get Elite Jobs. Princeton, NJ: Princeton University Press.

Rubin, Aviad, and Yusuf Sarfati, . 2016. The jarring road to democratic inclusion: A comparative assessment of state-society engagements in Israel and Turkey. London: Lexington Books.

Rustow, Dankwart. 1964. "Political Modernization and the Turkish Military Tradition." In Political Modernization in Japan and Turkey, edited by Robert Ward and Dankwart Rustow. Princeton, NJ: Princeton University Press.

Sabah. 2007. "Öymen: AKP'nin Başarısı Mantıklı Değil." Sabah, July 23.

—. 1999. "Arkadaşlar Caydırd1." Sabah, April 21.

Saito, Hiro. 2006. "Reiterated commemoration: Hiroshima as national trauma." Sociological Theory 24 (4): 353-376.

Seawright, Jason, and John Gerring. 2008. "Case Selection Techniques in Case Study Research: A Menu of Qualitative and Quantitative Options." Political Research Quarterly 61 (2): 294-308.

Shapiro, Yonathan. 1991. Road to Power: Herut Party in Israel. Albany, NY: State University of New York Press.

Sherman, Rachel. 2017. "Conflicted cultivation: Parenting, privilege, and moral worth in wealthy New York families ." American Journal of Cultural Sociology 5 (1-2): 1-33.

Shmuelli, Smadar, Oren Reiss, and Vered Lovitch. 2000. "Lea Rabin passed away at "Beylinson" Hospital." Ynet. November 12. Accessed October 14, 2014. http://www.ynet.co.il/articles/0,7340,L-182308,00.html. 
Simko, Cristina. 2018. "From difficult past to imagined future: Projective reversal and the transformation of ground zero." Poetics 67 (1): 39-52.

Smith, Philip. 2005. Why war? The cultural logic of Iraq, the Gulf War, and Suez. Chicago: The University of Chicago Press.

Snow, David, and Robert Benford. 1988. "Ideology, Frame Resonance, and Participant Mobilization." International Social Movement Research 1: 197-218.

Somer, Murat. 2016. "Understanding Turkey’s democratic breakdown: old vs. new and indigenous vs. global authoritarianism ." Southeast European and Black Sea Studies 16 (4): 481-503.

Somers, Margaret R. 1994. "The narrative constitution of identity: A relational and network approach." Theory and Society 23 (5): 605-649.

Türkmen-Dervişoğlu, Gülay. 2013. "Coming to terms with a difficult past: The trauma of the assassination of Hrant Dink and its repercussions on Turkish national identity." Nations and Nationalism 19 (4): 674-692.

Tamer, Rauf. 1999. "Değişik Bir Yapı." Sabah, May 26.

Tepe, Sultan. 2008. Beyond sacred and secular: Politics of religion in Israel and Turkey. Stanford, CA: Stanford Univ. Press.

Thirani Bagri, Neha. 2017. "An unfortunate side effect of collective identity is collective trauma ." Quartz. January 20. Accessed March 29, 2017. https://qz.com/889753/trumpinauguration-collective-trauma/.

Tuncay, Mete. 2000. Türkiye Cumhuriyeti'nde Tek Parti Yönetiminin Kurulmast: 1923-1931 [The Foundation of the Single Party Regime in Turkey: 1923-1931]. İstanbul: Tarih Vakfi Yurt Yayinları.

Turan, İlhan. 2002. İsmet İnönü ve Tek Dereceli İlk Seçimler. Ankara: İnönü Vakfi. Ulus. 1950. Ulus, May 5.

Vinitzky-Seroussi, Vered. 2009. Yitzhak Rabin's assassinations and the dilemmas of commemoration. Albany, NY: SUNY Press.

Viterna, Jocelyn, and Kathleen M. Fallon. 2008. "Democratization, Women's Movements, and Gender-Equitable States: A Framework for Comparison." American Sociological Review 73 (4): 668-89.

Wagner-Pacifici, Robin. 2001. "Prolegomena to a paradigm: Narratives of surrender." Qualitative Sociology 24 (2): 269-281.

Walzer, Michael. 2015. The paradox of liberation: Secular revolutions and religious counterrevolutions. New Haven, CT and London: Yale University Press.

Weiss, Shevah. 1979. Ha-Mahapach, Mai 1977-November 1978. Tel Aviv: Am Oved.

Weitz, Yechiam. 2011. "The Two Souls: Menachem Begin as Prime Minister (1977-1983) [Hebrew]." In From Altalenah to the Present Day: The History of a Political Movement from Herut to Likud, edited by Abraham Diskin, 194-227. Jerusalem: Carmel.

Willyard, Jennifer, and Kurt Ritter. 2005. "Election 2004 concession and victory speeches: The influence of genre, context, and speaker on addresses by presidential and vice presidential candidates." American Behavioral Scientist 49 (3): 488-509.

Yıldırmaz, Sinan. 2004. "1950 Seçimleri ve Propaganda." İstanbul Üniversitesi, Atatürk İlkeleri ve İnklap Tarihi Enstitüsü Yakın Dönem Türkiye Araştırmaları Dergisi 6: 131-157.

Yalçın, Hüseyin Cahit. 1950. Ulus, May 6.

Yarktzi, Dana. 2015. The Garbuz storm: 'trinket kissers and idol worshipers have taken over the country'. March 8. Accessed March 30, 2017. http://elections.walla.co.il/item/2836085. 
Yechimovitch, Shelly. 2015. Yechimovitch attacked the Left: In our camp there is an elitist condescention toward the periphery and Mizrachim. November 2. Accessed March 30, 2017. http://www.haaretz.co.il/news/politi/1.2766296.

Yuval, Amnon. 2015. "Lakum etmol baboker: Al hahitnahagut ha-elektoralit hapost-traumatit shel kvutzut hazehut beyisrael [Waking up yesterday: On the post-traumatic electoral behavior of identity groups in Israel]." Soziologia Yisraelit 17 (1): 147-153.

Zürcher, Erik Jan. 1991. Political Opposition in the Early Turkish Republic: The Progressive Republican Party, 1924-1925. Leiden: Brill.

Zelikovich, Moran. 2005. "Mazouz: Who said Rabin was assassinated due to incitement?" Ynet. August 10. Accessed October 14, 2014. http://www.ynet.co.il/articles/0,7340,L3125319,00.html.

Zemer, Hanna. 1982. "May a government of evil pass from this country." Davar, September 20: 1. 
TABLE 1 - KEY DETAILS ABOUT FOUNDING POLITICAL ELITES IN TURKEY AND ISRAEL

\begin{tabular}{|c|c|c|}
\hline & Turkey & Israel \\
\hline $\begin{array}{l}\text { Main party associated } \\
\text { with the founding } \\
\text { political elite }\end{array}$ & Republican People's Party (CHP) & $\begin{array}{l}\text {-The Workers' Party of the Land of } \\
\text { Israel (MAPAI) (1930-1968) } \\
\text {-The Israeli Labor Party (1968-) }\end{array}$ \\
\hline Ideology & Kemalism & Socialist Zionism \\
\hline First leader & Mustafa Kemal Atatürk & David Ben-Gurion \\
\hline Established & 1923 & 1930 \\
\hline Type of domination & $\begin{array}{l}\text {-Until 1950: Single party rule } \\
\text { (First multi-party elections held in } \\
\text { 1946) }\end{array}$ & $\begin{array}{l}\text {-Before 1948: Domination of } \\
\text { Jewish institutions in Palestine. } \\
\text {-After 1948: Largest party in } \\
\text { parliament; relative freedom in } \\
\text { forming coalition }\end{array}$ \\
\hline First political loss & 1950 & 1977 \\
\hline $\begin{array}{l}\text { Major political } \\
\text { successors }\end{array}$ & $\begin{array}{l}\mathrm{DP} \\
\mathrm{AKP}\end{array}$ & Herut / Likud \\
\hline \multicolumn{3}{|c|}{ Historical events analyzed for each group } \\
\hline Example 1 & $\begin{array}{l}1960 \text { - Military coup (the DP } \\
\text { ousted) }\end{array}$ & 1982 - Sabra and Shatila Massacre \\
\hline Example 2 & $\begin{array}{l}1999 \text { - The CHP fails to pass the } \\
10 \% \text { electoral threshold }\end{array}$ & $\begin{array}{l}1995 \text { - Labor leader Yitzhak Rabin } \\
\text { assassination }\end{array}$ \\
\hline Example 3 & $\begin{array}{l}2007 \text { - The AKP's landslide } \\
\text { victory (won } 46.6 \% \text { of the votes) }\end{array}$ & $\begin{array}{l}1996 \text { - Electoral victory for the } \\
\text { Likud }\end{array}$ \\
\hline
\end{tabular}

